\title{
Left-Wing Governmental Alliance in Portugal, 2015-2019: A Way of Renewing and Rejuvenating Social Democracy?*
}

\author{
André Freire ${ }^{1}$ \\ https://orcid.org/0000-0001-5307-6832 \\ 1University Institute of Lisbon - ISCTE-IUL - Political Science \& \\ Public Policies, Lisbon, Portugal
}

The 2015-2019 left-wing government alliance in Portugal merits attention for several reasons, of which four stand out. First, because, if it worked well, it may offer a solution to the crisis affecting socialdemocratic parties by pushing them back to the left. Second, because it may offer the radical left greater influence. Third, because existing studies offering comprehensive overviews of the Portuguese case tend to be descriptive in nature. Fourth, because existing studies that are more analytical and explanatory in nature tend to be rather limited in their scope. This study offers an original contribution in that it uses empirical data and takes a comprehensive, analytical and explanatory approach. We argue that the crisis was an important factor in changing old patterns of coalition politics on the Left in Portugal, both because it brought the socialists and radical left parties together in government, and because these changes were very important in guiding the socialists to shift in their policy orientations. Broadly, we argue that the new patterns of coalition politics on the Left and an increased influence of the radical left on domestic politics offer a means of renewing and rejuvenating social democratic parties in Portugal and elsewhere.

Keywords: Left-wing government alliance; Portugal; austerity; Great Recession; social democratic decline; radical left influence.

http://doi.org/10.1590/1981-3821202100020004

For data replication, see: https://doi.org/10.7910/DVN/X07ZKQ

Correspondence: André Freire. E-mail: andre.freire@iscte-iul.pt

This publication is registered under a CC-BY Licence.

*The author wishes to acknowledge the collaboration of the PhD student at ISCTE-IUL (and research assistant at CIES-IUL, "Observatory of Democracy and Political Representation"), Viriato Queiroga, for his assistance with the formal editing of this article. The author would also like to thank the editors of the Brazilian Political Science Review and the three anonymous reviewers for their contribution towards improving the article. 
$\mathrm{T}$ he 2008 global economic crisis has had dramatic consequences for democratic political systems, especially in Southern Europe, a region characterised by increasing electoral volatility, significant changes to party systems, the emergence of new political parties, the mobilisation of new social movements, increasing governmental instability and declining satisfaction with democracy (BAILEY et al., 2014a; BARTELS and BERMEO, 2014; FREIRE et al., 2015a, pp. 385-410; FREIRE et al., 2015b, pp. 19-48; FREIRE and LISI, 2016b, pp. 153-171; MATTHIJS, 2014, pp. 101-115; ROCA et al., 2018).

While these challenges have caused a deep crisis within social democratic parties, the effect of the economic turmoil on parties of the radical left is still unclear (LAVELLE, 2014, pp. 270-284; LAVELLE, 2008; MARCH, 2011; MARCH, 2008; MARCH and FREIRE, 2012, p. 27)22. However, for social democratic parties the crisis is both a problem and an opportunity for renewal and rejuvenation (BAILEY et al., 2014a, pp. 01-18). On the one hand, this is because the international crisis and the European sovereign debt crisis have revealed the failure of neoliberal ideas and policies, as well as institutional problems with European Union's (EU) process of economic and monetary integration (EMU: European Monetary Union) (BLYTH, 2012; RODRIK, 2012). The bloc of social democratic parties in the EU aligned with with many of these orientations and policies, contrary to the radical left parties that have always opposed them (LAVELLE, 2008). On the other hand, the implementation of austerity packages in various countries, but especially Greece and Portugal, has had devastating socioeconomic, financial and political consequences. Moreover, this context has revealed the difficulty of changing the EU status quo through democratic means (ALONSO, 2014), and thus of the need for radical democratic change in Europe: something that has always been at the forefront of the radical left's proposals. Additionally, while in Greece the radical left 'Syriza' benefited a great deal from this set of conditions, and in Spain 'Podemos' also seems to be benefiting, in many countries it is the radical right, and not the radical left, that is profiting from the crisis (BARTELS and BERMEO, 2014). However, and this is our final consideration in relation to the Portuguese case, if a new politics of left and centre-left alliances can be put into action, as is the case with Portugal's

${ }^{2}$ For a definition of the radical left, see also MARCH and FREIRE, 2012, p. 27.

(2021) $15(2) \quad$ - $00004-2 / 34$ 
government between 2015 and 2019 (a minority Socialist Party government kept in power through a series of parliamentary agreements with parties of the radical-left: the Left Bloc, the Portuguese Communist Party and the Greens), then the balance of power can begin to alter the neoliberal status quo. This may be especially effective if this new politics of alliances is adopted in other EU countries, increasing the possibility of changing the status quo in the EU: remember we now have a new governmental alliance of the socialists and radical left (Podemos, UP) in Spain as of January 2020.

The 2015-2019 left-wing government alliance in Portugal is worth studying for several reasons. On the one hand, because it worked well, it can offer both a solution to the crisis affecting social democratic parties (caused largely by their convergence with the neoliberal agenda) by pushing them back to the left, and furnish the radical left with an opportunity to gain further influence. On the other hand, it is worth studying because this solution is rarely adopted in contemporary Europe, where grand coalitions and/or rainbow alliances (with or without social democratic party involvement) are much more common ${ }^{3}$, and because the Portuguese left-wing alliance has been rather successful in both political and economic terms, producing political stability, higher GDP and lower unemployment among other achievements. Finally, and despite the reversal of austerity policies, the 2015-2019 government alliance was compliant with EU economic and financial rules. Moreover, the Portuguese solution has received growing domestic and international interest from journalists and left-wing politicians from other countries who have come to see what is happening and take home some inspiration (ESTANQUE et al., 2018, pp. 111-133; FERREIRA et al., 2017; FREIRE, 2017; SERRANO, 2018, pp. 17-47).

On the academic front, there are three main reasons why this study can add important knowledge (and data) to our understanding of the 2015-2019 Portuguese

\footnotetext{
${ }^{3}$ It is true that there are some exceptions to this, such as the left-wing government alliances in Spain (January 2020-present) and Portugal (2015-2019). However, both currently and in the recent past, either grand coalition politics (like Germany today, with the alliance of CDU/CSU with SPD; Austria during much of the post-War era, with the alliances of ÖVP with SPÖ; in Spain for the accession of Mariano Rajoy in 2016, and when the constitution was changed to adapt to the new EU fiscal treaty - the golden clause brake; the support for the Letta government in Italy in 2013; and rainbow alliances (with or without social democratic party involvement, like the coalitions put together by parties of the Left and Right in Finland, in Greece between Syriza and the Independent Greeks, in the Netherlands, etc), have been much more common in European politics than left-wing alliances.
} 
government alliance, and its implications for the European left. First, existing studies offering more comprehensive overviews of the Portuguese case tend to be descriptive in nature (FERREIRA et al., 2017; FINN, 2017, pp. 05-32). Second, existing studies that are more analytical and explanatory in nature tend to be rather limited in their scope (DE GIORGI and SANTANA-PEREIRA, 2016, pp. 451-468; LISI, 2016, pp. 541-560). This study, by contrast, offers an original contribution in terms of data used and, particularly, in terms of its perspective, which is both comprehensive (in that it considers the roots, characteristics and results of the left-wing alliance in Portugal) and adopts an analytical and explanatory approach. Additionally, some previous studies of social democratic responses to the Great Recession did not consider the Portuguese experience (BAILEY et al., 2014a), while others were more focused on radical left parties' responses and were written before the left-wing alliance was formed (MARCH and KEITH, 2016). Therefore, they clearly need to be updated.

We derive our main research question from this context, while three supplementary research questions are derived from the first. Our fundamental research question is the following: what is the relative impact of the crisis (i.e. both the Great Recession and the sovereign debt crisis) on changing patterns of coalition politics on the Left in the Portuguese case, namely the alliance for government of the social democrats (i.e. the socialists in Portugal, PS) and the radical left (Communist, PCP, Greens, PEV, and the left-libertarian Left Bloc, BE)? From that main research question we derive three additional ones. First, can these changes in coalitional politics on the Left be said to be important routes for the renewal and rejuvenation of social democracy in Portugal (and elsewhere)? Second, are there signs of fundamental changes in social democratic policy orientations in Portugal, following the crisis and the new pattern of coalition politics, that can be said to contribute to the renewal and rejuvenation of social democracy? Third, did the new pattern of coalition politics on the Left really translate into the greater influence of radical left parties, and at what electoral price?

Our major findings are the following: first, we show that the crisis did have an impact (although alongside other factors) in changing the patterns of coalition politics on the Left in the Portuguese case. Second, we show that these changes 
in coalitional politics on the Left can be said to be important routes for the renewal and rejuvenation of social democracy in Portugal (and elsewhere), because, as Wolfgang Merkel and his colleagues demonstrated some time ago, coalitions between social democrats and the radical left are a fundamental way of avoiding, or pushing back against, the neoliberalisation of social democratic parties, and the radical left has exercised significant influence over changes in socialists' policy orientations (LAVELLE, 2014; MERKEL et al., 2011). Third, we show that there are some signs of changes in social democratic policy orientations in Portugal, namely by contesting approaches mainly based upon austerity, although the left-wing alliance was also pretty conservative in fiscal terms in complying with EU rules. Finally, we show that the new pattern of coalition politics on the left really implied greater influence of the radical left parties (as mentioned above in terms of policy influence), but electorally (October 06, 2019, national elections) the 'Partido Socialista' (Socialist Party, PS) seem to have benefited the most. The left bloc (BE) retained the same number of MPs and suffered a slight decline in number of votes, while the communists (PCP_PEV) declined significantly in terms of both MPs and votes.

Theory and 'descriptive hypothesis': the Great Recession as a stimulus for social democratic renewal and rejuvenation, and for increasing radical left influence

As said above, the Great Recession in Europe can be said to have been both a problematic context for social democratic parties, a crisis factor, and an opportunity for renewal and rejuvenation if they are able to adapt both their coalitional politics and policy orientations. One reason for this is that the Great Recession and the European sovereign debt crisis have revealed the failure of neoliberalism, which social democrats have also adopted to greater or lesser degrees. By contrast, radicalleft parties have always fought those neoliberal policies. Moreover, Bailey, De Waele, Escalona and Vieira, in a 2014 book about social democratic responses to the Great Recession, consider that a paradox emerged from the Great Recession (BAILEY et al., 2014b, pp. 01-03). On the one hand, the crisis revealed the failures of neoliberalism, namely those related to the deregulation of financial and housing markets, which resulted in a Global financial crisis. Thus, these problems seem to demand typical social democratic policies: "financial regulation, housing market regulation, 
fiscal reflation and redistribution, quantitative easing, a tempering of austerity and a defence of the welfare state (...)". However, on the other hand, "despite a crisis of neoliberalism, no clear and viable social democratic alternative appears to have (thus far) been forthcoming" (BAILEY et al., 2014b, pp. 01-02). But we should emphasize that this book does not include the Portuguese left-wing government alliance. In the concluding chapter of the same book, by Ashely Lavelle (2008, pp. 277-279), the hope for such a social democratic alternative is placed more on the new social movements protesting against austerity (like the 'Indignados' in Spain, and their followers elsewhere) and the radical left parties that gained prominence on the left, at least in some countries. In a similar vein, although in a different context (a study of the performance and policies of social democratic parties during the 1990s and 2000s in France, Denmark, Germany, Holland, Sweden and the United Kingdom), Wolfgang Merkel and his colleagues concluded that alliances of social democratic parties with both the union movement and/or the radical left parties are among the factors that better equipped the social democratic parties to resist the pressures of neoliberalisation (MERKEL et al., 2011, pp. 208-252). And we know that in the Portuguese case there was a significant articulation between social movements (old and new) and left parties (both socialists and the radical left) not only to fight austerity under the right-wing government, but also in creating the conditions for the left-wing government alliance (ESTANQUE et al., 2017).

Based on these considerations we draw four 'descriptive hypothesis' or, put in simpler terms, general expectations. We call them descriptive hypothesis because we are only extrapolating from a single case study; however, we believe that the 40year schism within the Portuguese left makes this a valid case for making such extrapolations. Thus, our main descriptive hypothesis or expectation is the following: we expect that the crisis has had a positive role on the changing patterns of coalitional politics on the left in the Portuguese case, strengthening the basis for coalition building (H1). Three further descriptive hypothesis or expectations may be derived from this first one. In second place, we also consider that these changes in coalitional politics on the left are important routes for the renewal and rejuvenation of social democracy in Portugal (and elsewhere) (H2). Due to the longterm (during the so-called neoliberal era) convergence of social democratic parties 
with neoliberal actors (in coalitional politics) and, in particular, with neoliberal policy orientations, alliances with the radical left can be an effective way to renew social democracy by changing the patterns of alliances and by pushing social democrats further to the left in their policy positions, under the influence of the radical left. Moreover, these elements of renewal in terms of political alliances and/or public policies can also help to bring about rejuvenation in terms of the personnel involved in the leadership of social democratic parties. Third, we expect to see significant changes in social democratic policy orientations in Portugal following the crisis and the new pattern of coalitional politics (H3), which are related to a growing influence of the radical left upon the socialists in power (H4).

\section{The Great Recession and ideological change within the radical left in Portugal}

The Great Recession emphasised the three main problems affecting the radical left in Portugal during the democratic period. The first is the high degree of fragmentation on the left of the political spectrum, which stands in stark contrast with the stability and coherence found on the right. The second is the unwillingness, prior to the 04 October 2015 election, of left-wing parties to co-operate with one another. The third concerns the differences that had, until October 2015, separated the PS from the radical left.

The process of democratisation in Portugal resulted in the 'Partido Comunista Português' (Portuguese Communist Party, PCP) being marginalised in comparison to the PS, the 'Partido Social Democrático' (Social Democratic Party, PSD) and the 'Centro Democrático' e 'Social-Partido Popular' (Social and Democratic Centre-Popular Party, CDS-PP) ${ }^{4}$. The PCP has played the role of an 'anti-system' party, while the PS has adopted more moderate positions, especially with regard to socioeconomic issues (BOSCO, 2001, pp. 329-387). The ideological distance between the PCP and the PS was based mainly on their attitude towards

\footnotetext{
4The PCP, plus the Ecological Party and the Greens (PEV), always stood in coalition since 1987 as the 'Coligação Democrática Unitária' (United Democratic Coalition, CDU). PCP is a party of the far left, 'conservative/orthodox communist' depending on the designation; PEV is a green-red party, in fact a satellite of PCP that never went to the polls alone. In the European Parliament PCP (as well as PEV) is a member of the European United Left-Nordic Green Left (GUE-NGL) bloc. The PS is a centre-left party and member of the Socialist and Democrat group in the European Parliament. The PSD is on the centre right and the CDS-PP is on the conservative right, with both being members of the European People's Party (EPP).
} 
democracy, the EU and the legacy of the Carnation Revolution, particularly with respect to the nationalisation of large private companies, landed estates and banks. Despite the erosion of the PCP's electoral and parliamentary support (see Figure 01 ), the party has resisted competition from the extra-parliamentary left to remain the main institutional alternative to the left of the PS.

Figure 01. National Parliamentary performance of parties of the Left: Legislative Elections, 1975-2015

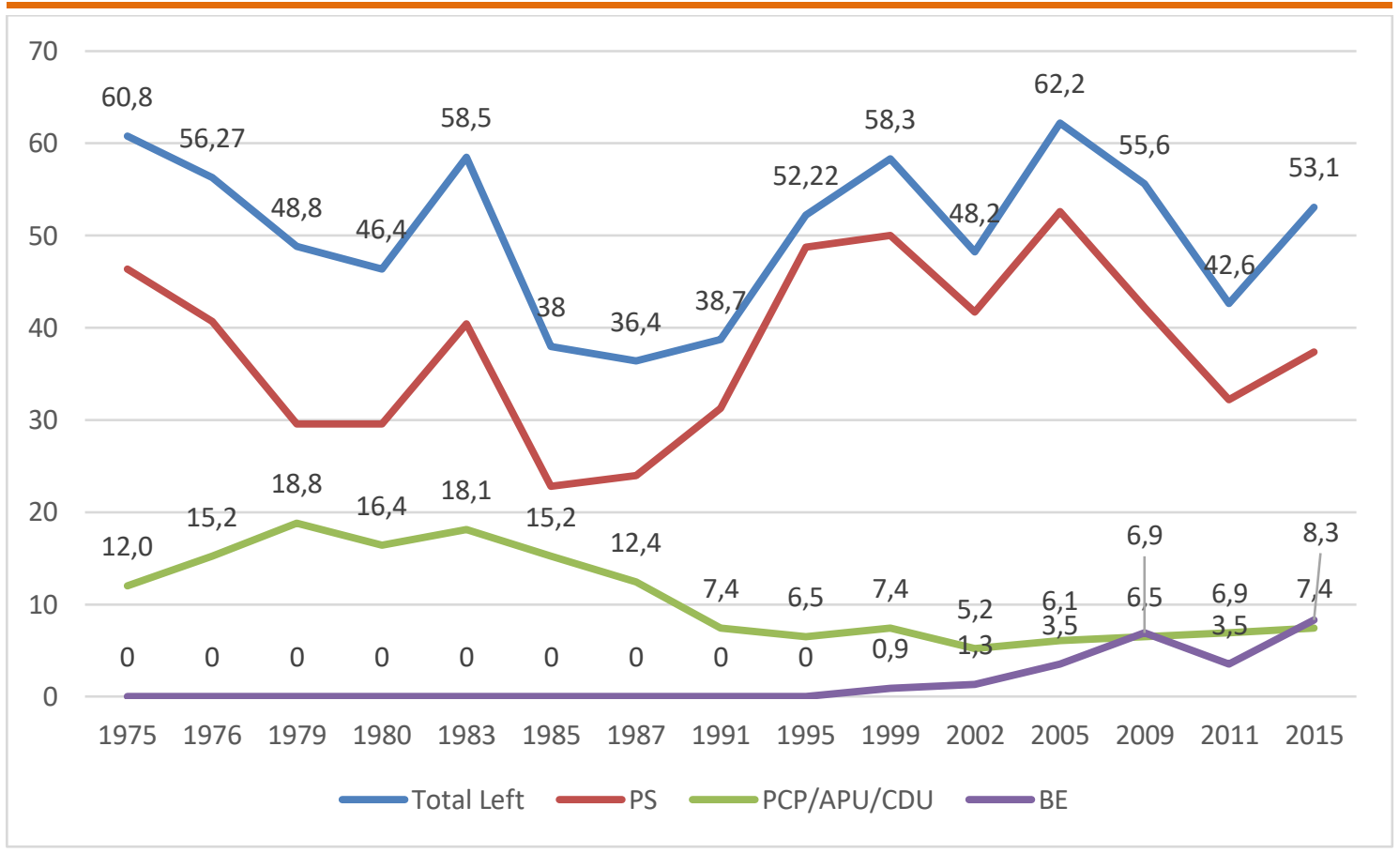

Sources: Data elaborated by the author and taken from March and Freire (2012, p. 204).

Note: 1975-2011, always bearing on the official results published by CNE (National Electoral Commission): see www.cne.pt .

Notwithstanding some attempts to reform and moderate the ideological orientation of the PCP, both before and after the collapse of the USSR, the Party remains one of the most orthodox communist parties in Western Europe (KEITH and CHARALAMBOUS, 2016, pp. 147-161; MARCH, 2008). The PCP's institutional predominance within the radical left was challenged in 1999 when the 'Bloco de Esquerda' (Left Bloc, BE) first elected representatives to parliament ${ }^{5}$. BE was the

5In 2000, the 'Frente da Esquerda Revolucionária' (Revolutionary Left Front, FER) joined the Party to become its fourth organised component. In the European Parliament, the BE is also a member of the the European United Left-Nordic Green Left (GUE-NGL) bloc. 
result of a merger of two parties of the radical left, the 'Partido Socialista Revolucionário' (Socialist Revolutionary Party, PSR), originally Trotskyist, and the 'União Democrática Popular' (Popular Democratic Union, UDP), originally Maoist, with the 'Política XXI' movement, a dissident faction of the PCP and their allies in 'Movimento Democrático Português/Centro Democrático Eleitoral' (Democratic Portuguese Movement/Democratic Electoral Center, MDP/CDE). Despite sharing strong anti-capitalist positions, BE and PCP differ on a few key issues. The former has sought to reform democracy by enhancing participatory channels while accepting the main liberal institutions, it has been very critical of the USSR and has supported a new transnationalism based on the calls of socio-political movements for a different kind of globalisation. By contrast, the PCP is less critical of the USSR, more critical of liberal democracy, and has adopted a more nationalistic response vis-à-vis both the EU and globalization.

What were the consequences of the post-2008 recession, the bailout and the enforcement of the MoU (i.e. 'Memorandum of Understanding', the name given in Europe to the agreements between the Troika - European Central Bank, European Commission and the International Monetary Fund - and the bailed out countries, like Portugal) for the ideological positioning of the radical left in Portugal? Based on its manifestos for the 2011 parliamentary and 2014 European elections, the new programmes and statutes approved at the 19th Congress, and the 2015 election manifesto ${ }^{6}$, we have identified five major elements associated with a further radicalisation of the PCP. First, the preceding $35-40$ years of democracy under PS, PSD and CDS-PP governments were all characterised by the predominance of right-wing policies. Second, an increasing sense of nostalgia for the era of 'real socialism' under Soviet influence, even while acknowledging the existence of serious operational problems. Third, PCP's strongly nationalistic Euroscepticism has become more vocal, with the party now calling for the dissolution of European economic and monetary union', which effectively means an end to the single currency, or at least Portugal's membership of it (FREIRE and LISI, 2016a). Fourth, the call for large-scale renationalisation of strategic economic

${ }^{6}$ For the ideological positions the parties of the Left between 2011 and 2015, see their manifestos: Bloco de Esquerda (2015b, 2011); Partido Comunista Português $(2015,2011)$; Partido Socialista $(2015,2011)$. 
sectors, including banks and utilities. Fifth, PCP supports the renegotiation of public debt (in terms of volume, interest rates and maturities).

With some exceptions, the BE's positions during the post-2008 recession were not so different from that of PCP (BLOCO DE ESQUERDA, 2015a, 2015b, 2013, 2011). The party also rejected the Troika bailout and similarly called for the renegotiation of Portugal's public debt following an audit. It also believes there is a need for peripheral EU countries, especially those most affected by the debt crisis, to come together to oppose the EU's austerity-driven neoliberal approach. Like the PCP, the BE calls for greater fairness in the distribution of income between capital and labour, which is associated with calls for the state and public sector to play a powerful role in society and the economy, and for increased public investment and enhanced social rights.

The major ideological difference between BE and PCP relates to their attitudes and policies towards Europe. Thus, while the BE presents a radical critique of EU integration, unlike the PCP it advocates an alternative, left-wing and progressive vision for Europe that is not anchored in nationalism. However, developments in the Portuguese economy and the Greek crisis in 2015 led to a growing convergence between the BE and the PCP in their criticisms of the EU (HOOGHE et al., 2010, pp. 687-703). Overall, both parties of the radical left have a very similar diagnosis of the crisis, although their proposed solutions differ slightly.

\section{The radical left's difficult road to co-operation with the PS}

At the end of 2015, following the 04 October parliamentary elections and the formation of the 21st constitutional government on 27 November, Portugal was one of the few Western European countries in which parties of the radical left had, since the fall of the Berlin Wall, never participated in left-left governments (either as members of a coalition or as parliamentary support parties for centre-left governments) (BALE and DUNPHY, 2011, pp. 269-291; MARCH, 2011, 2008; MARCH and FREIRE, 2012, p. 27; FREIRE, 2017). Prior to 1989, the Portuguese case was comparable to those of most Western European countries, where the only countries that had seen left-left (or rainbow) governments were Iceland, Finland and France. Aside from geopolitical factors, which also applied to other countries, 
additional factors contributed to the PCP's inability to integrate institutionally (MARCH and FREIRE, 2012). In particular, the PCP belongs to a subgroup of more orthodox communist parties in Western Europe, meaning that, unlike the Eurocommunists, it was fairly close to the USSR and less willing to compromise with the PS. Furthermore, the electoral and organisational strength of the PCP relative to that of the PS was much greater in 1987-89 than it has been subsequently. This harmed the possibility of reaching an agreement because at that time the PS was afraid to align itself with such a powerful rival.

According to the typology of parties of the radical left (MARCH, 2011, 2008) - which, among other things, differentiated between the 'extreme left' sub-family (to which the PCP belongs), which is less willing to compromise for government with the social democrats, and the 'radical left' (to which belongs the BE), which is more willing to compromise for government with the social democrats - the 'radical' BE was expected to be more open to co-operating with the PS than the 'extreme' PCP. Yet, neither the PCP nor the BE had been able to establish any form of collaboration with PS or create new government solutions, either before or during the crisis period. In addition to ideological and policy differences, the legacy of democratisation, the incapacity to achieve a compromise at the elite level, and strategic considerations were also important factors accounting for the lack of agreement (LISI, 2016, pp. 541-560). Other factors are also worth noting, although there is not space to develop them here: a lack of pressure from the unions (BALE and DUNPHY, 2012, pp. 32-49; BALE and DUNPHY, 2011, pp. 269-291; DUNPHY and BALE, 2011, pp. 488-504), the absence of widespread left-left alliances at the local or regional level to serve as examples ${ }^{7}$, and unwillingness of political elites to compromise (FREIRE, 2017; LISI, 2016, pp. 541-560; MARCH and FREIRE, 2012).

How has the Great Recession influenced patterns of co-operation between left-wing parties? We begin our analysis by looking at the overall ideological position of parties on the left-right continuum both before and after the crisis. According to surveys of deputies carried out in 2008 and 2012-13, there is a clear move to the right by right-wing parties (PSD and CDS-PP), while left-wing parties (PS, BE and PCP) have moved further to the left (FREIRE et al., 2016a;

\footnotetext{
${ }^{7}$ Lisbon (1989-2001 and 2007-present date), Funchal (2013-present date) and some other local town councils since the 2017 local elections are the only examples of previous political alliances of radical left with the socialists, before the XIII legislature (2015-2019).
} 
FREIRE et al., 2015a, pp. 385-410). The result of this is a system that is now more polarised than ever at the elite level but not at the citizen level (FREIRE et al., 2016a). This suggests that since the 2011-13 crisis the policy incongruence between the parliamentary elite and voters has become greater than it was in 2008. Moreover, on the left, the PS is more in tune with its voters than either the BE or PCP are with theirs (FREIRE et al., 2016a; MARCH and FREIRE, 2012) ${ }^{8}$. Furthermore, the campaign for the 2015 general elections showed that significant differences remained between the PS and the radical left with regard to such important policies as debt renegotiation, the renationalisation of strategic sectors and EU reform. These findings are also confirmed by observations of party behaviour at the parliamentary level (DE GIORGI and SANTANA-PEREIRA, 2016, pp. 451-468; DE GIORGI et al., 2015, pp. 54-74).

In any case, the absence of left-left government solutions in Portugal created a large mismatch between the left-wing voters (who clearly supported agreements) and their party and/or parliamentary representatives (who remained far more reluctant). The results presented in Table 01 show that a majority of PCP and BE voters and a plurality of PS voters are in favour of left-left governments. The results for both 2009 and 2012 were rather similar (MARCH and FREIRE, 2012; FREIRE et al., 2015a).

However, the situation in Portugal changed significantly following the general election on 04 October 2015 (see Table 02) and the subsequent formation of the 21st constitutional government. According to the results, the right-wing 'Portugal à Frente' (Portugal Ahead, PàF), a pre-electoral coalition between the PSD and CDS-PP, obtained most votes, with the PS second in terms of votes and parliamentary seats. However, when the results for all parties of the left were counted, it was clear that the PS, BE and PCP-PEV combined had won an absolute majority of both votes cast and of seats.

As stated above, a number of surveys had shown there to be widespread voter support for either a left-wing government alliance, particularly among voters who identified themselves as being on the Left. What had been missing before was support for this among party elites because, as shown in Figure 01, many

\footnotetext{
${ }^{8}$ For previous periods, but with data pointing in the same direction, see MARCH and FREIRE (2012,
} Part II). 
previous elections had returned left-left majorities in parliament to complement a PS plurality of seats, left-left agreements for government were never achieved.

Table 01. Portuguese attitudes towards left-wing governments (2014) - sympathy by party (\% of each group total)

Q: Imagine the general election has been held and that the PS won, but without an absolute majority. Which one of the following options do you think would be better for the country (choose only one)? It would be better for the country for the PS to...

Rule in minority

Form a coalition with the radical left

Form a coalition with the right

Form a coalition with all parties $\mathrm{N}$

\begin{tabular}{lllll} 
CDU/PCP & BE & PS & PSD & CDS-PP \\
\hline 11.1 & 12.8 & 21.1 & 19.3 & 11.9 \\
69.1 & 66.7 & 41.8 & 7.5 & 7.2 \\
2.5 & 5.2 & 21.6 & 54.1 & 57.2 \\
17.3 & 15.4 & 15.4 & 19.3 & 23.8 \\
81 & 39 & 227 & 161 & 42
\end{tabular}

Source: Data elaborated by the author based on a representative sample of the adult population living in mainland Portugal, $\mathrm{N}=1205$, survey conducted between June and October 2014. See Belchior, Silva and Queiroga (2014).

Table 02. Elections to the Portuguese Parliament (2015, 2011 and 2009)

\begin{tabular}{|c|c|c|c|c|c|c|c|c|c|}
\hline \multirow[b]{3}{*}{ Parties } & \multicolumn{2}{|c|}{2015} & \multicolumn{4}{|c|}{2011} & \multicolumn{2}{|c|}{2009} & \multirow[b]{2}{*}{ Votes } \\
\hline & Seats & & Votes & Seats & & Votes & Seats & & \\
\hline & $\mathrm{N}$ & $\%$ & $\%$ & $\mathrm{~N}$ & $\%$ & $\%$ & $\mathrm{~N}$ & $\%$ & $\%$ \\
\hline PàF & 107 & 46.5 & 38.56 & - & - & 50.4 & - & - & 39.5 \\
\hline PSD & 89 & 39.0 & 32.0 & 108 & 46.9 & 38.7 & 81 & 35.2 & 29.1 \\
\hline PS & 86 & 37.4 & 32.3 & 74 & 32.2 & 28.1 & 97 & 42.2 & 36.6 \\
\hline $\mathrm{BE}$ & 19 & 8.3 & 10.2 & 8 & 3.5 & 5.2 & 16 & 6.9 & 9.8 \\
\hline CDS-PP & 18 & 7.8 & 6.56 & 24 & 10.4 & 11.7 & 21 & 9.1 & 10.4 \\
\hline PCP/PEV & 17 & 7.4 & 8.25 & 16 & 6.9 & 7.9 & 15 & 6.5 & 7.7 \\
\hline PAN & 1 & 0.43 & 1.39 & - & - & - & - & - & - \\
\hline Others & 0 & 0.0 & 5.16 & 0 & 0.0 & 4.4 & 0 & 0.0 & 3.1 \\
\hline $\begin{array}{l}\text { Spoiled } \\
\text { ballots }\end{array}$ & & & 4.14 & - & - & 4.0 & - & - & 3.1 \\
\hline Total & 230 & 100 & 100 & - & - & 100 & 230 & 100 & 100 \\
\hline Turnout & & & 56.1 & & & 58.0 & - & - & 60.5 \\
\hline
\end{tabular}

Sources: www.cne.pt.

Notes: In Portuguese elections spoiled ballots are counted as a percentage of the total vote; 'Portugal à Frente' (Portugal Ahead, PàF) was a pre-electoral coalition of the PSD and CDS-PP (except in Madeira, where they ran separately); the total vote for PàF (38.56\%) was disaggregated using the proportion of the 107 seats in parliament held by each of the parties in the coalition (PSD: 0.83; CDS-PP: 0.17 ) as a multiplier. PàF only ran together in 2015, but for the sake of comparing the electoral strength of the Right across elections we also calculate it for 2011 and 2009.

Therefore, the 21st constitutional government, a minority PS government supported by the BE, PCP and the PEV (in three separate agreements), is something new in Portuguese politics. Following the parliament's rejection of the very shortlived right-wing minority coalition 20th constitutional government, which survived for 11 days, the president was 'obliged' to appoint a prime minister and party that could command a majority in parliament, despite having come second in the 
general election. The 21st constitutional government was eventually named around 50 days after the election. The question was why only now, in late 2015 ? We believe there are eight main explanatory factors.

Figure 02. Left-Right Position of Portuguese Political Parties (from 1-left to 10-right) according to voter perceptions of the ideological locations of parties (based on representative mass surveys), 1978-2014

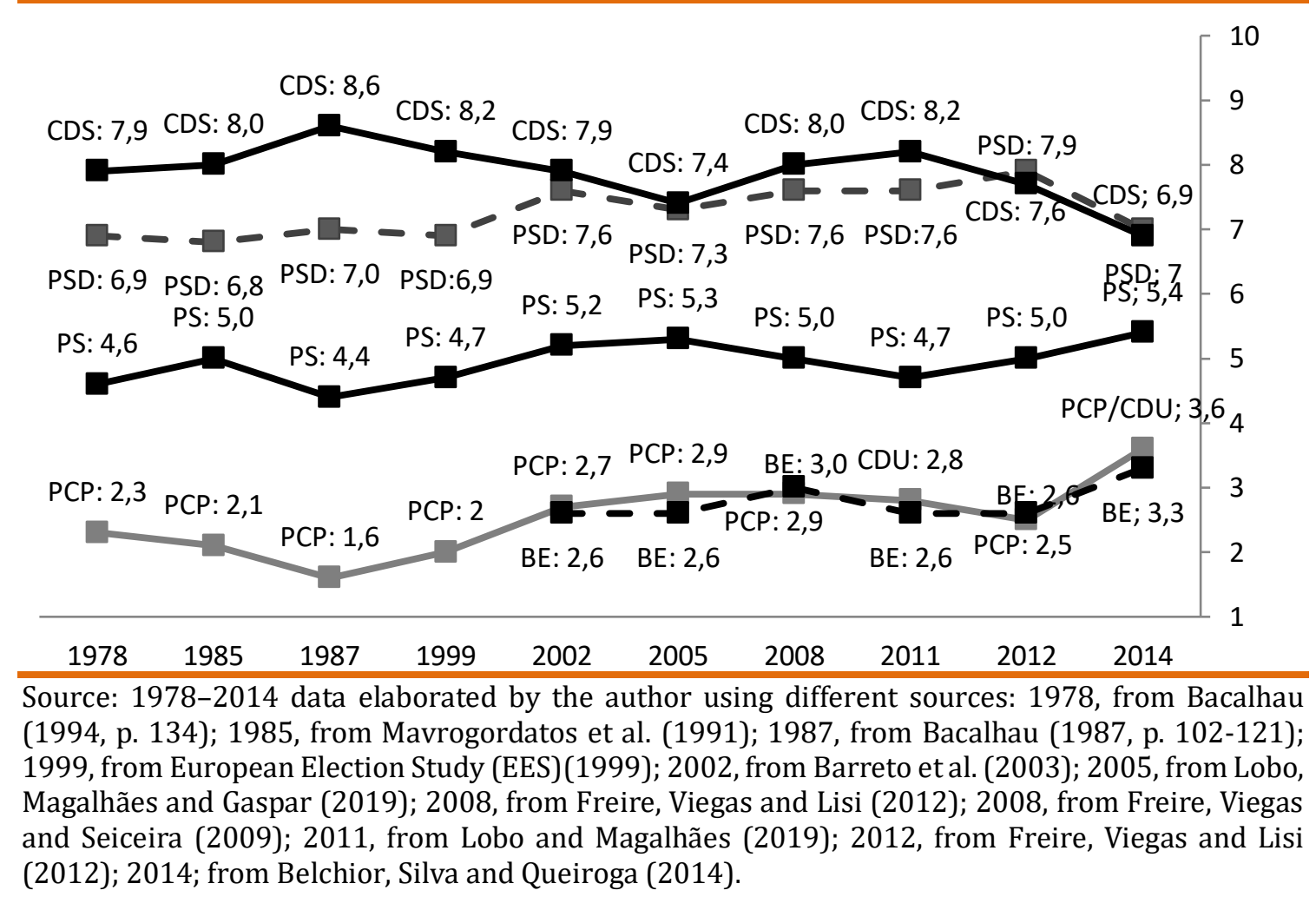

First, the right-wing parties made a significant shift to the right during the Troika years, which made any agreement between them and the centre-left PS less likely (FREIRE, 2017; FREIRE et al., 2016a). Data based on citizen perceptions of the position of Portuguese parties on the left-right scale between 1978 and 2015 (see Figure 01 and Table 03), confirm the PSD's significant shift to the right, and away from the average voter, since 2012. Similarly, the PS and both parties of the radical left had moved further to the left over this period, meaning that from 2012 to 2015 the Portuguese centre left and centre right were further apart than ever, at least in left-right ideological terms. These can also be seen in Table 03, which present the average left-right distance between parties - PS and CDS/PSD, then PS and BE/PCP. These shifts and distances clearly illustrate the greater difficulty of agreeing a 'grand coalition' between the two main parties (PS and PSD) since the Troika's 
arrival, and how much easier left-left agreements have become. Of course, pure leftright divides are not the only measure of important ideological difference between Portuguese parties. For example, on European issues, the gap between the PS and the parties to its left are perhaps greater than that between the PS and PSD. Moreover, it might be asked whether the left-right divide is a relevant divide at all in Portuguese politics; we know that it is, though much more strongly for parties than for voters (BENOIT and MICHAEL, 2006; BUDGE et al., 2001; FREIRE, 2017; KLINGEMAN et al., 2006).

Table 03. Left-Right (L-R) ideological distances between pairs of parties in Portugal, 19782015

\begin{tabular}{lllllll} 
& \multicolumn{5}{c}{ Date of mass survey measuring L-R position } \\
\cline { 2 - 7 } Distances between Parties & 1978 & 1987 & 2002 & 2012 & 2014 & 2015 \\
PS - CDS & $-3,3$ & $-4,2$ & $-2,7$ & $-2,7$ & $-1,5$ & $-3,7$ \\
PS - PSD & $-2,3$ & $-2,6$ & $-2,4$ & $-2,9$ & $-1,6$ & $-3,7$ \\
PCP - PS & $-2,3$ & $-2,8$ & $-2,5$ & $-2,5$ & $-1,8$ & $-2,3$ \\
BE - PS-PCP & & & $-2,6$ & $-2,4$ & $-2,4$ & $-2,2$ \\
\hline
\end{tabular}

Sources: 1978-2015 data elaborated by the author from different sources: 1978, from Bacalhau (1994, p.134); 1985, from Mavrogordatos et al. (1991); 1987 from Bacalhau (1987, p. 102-121); 1999, from European Election Study- EES (1999); 2002, from Barreto et al. (2003); 2012, from Freire, Viegas and Lisi (2012); 2014, from Belchior, Silva and Queiroga (2014); 2015, Lobo et al. (2019).

Second, the austerity measures introduced by the right-wing parties (PSD and CDS-PP) were severe, had unequal impacts and went far beyond both the Troika's requirements and the political mandate received from voters in 2011 (including much higher cuts to wages, pensions, public sector jobs and to the welfare state, and much more extensive privatisations) (FREIRE et al., 2015b, pp. 1948). Indeed, there was a very high level of asymmetry in the enforcement of austerity measures: the share of Portuguese wages in the country's GDP fell from $58.4 \%$ in 2010 to $55.6 \%$ in 2012 , and to $51.9 \%$ in 2015 ; moreover, during this period, Portugal reached its worst wage-to-GDP ratio since the 1960s (FREIRE, 2016a, p. 180).

Third, there were strong incentives for the leader of the PS, António Costa, to take power. He knew very well that his choice was to be prime minister of a centre-left government supported by the radical left, or his party would support a right-wing PàF government, and that in the latter scenario, someone else would be better suited for the job. 
Fourth, the Portuguese president is not allowed to dissolve parliament and call new elections during either the six months preceding presidential elections or the first six months of a new parliament. The presidential elections were due to be held in January 2016, while the earliest date the new president could dissolve parliament was April 2016 (DE GIORGI and SANTANA-PEREIRA, 2016).

Fifth, this left-left governmental solution offered a way to bring party elites in line with the preferences of a majority (or a plurality) of left-wing voters in supporting such a solution (Table 01).

Sixth, the perception among the PS leadership that there would be a serious risk of electoral collapse were it to shore up right-wing parties (as had happened with PASOK following the Greek elections of 2012 and 2015) and/or display excessive ideological centrism (as in the case of a number of European socialist/social democratic parties, such as the PSF in France, the Labour Party in the UK, the MSZP in Hungary and, more recently, PSOE in Spain) may also have contributed to a preference for this type of alliance rather than propping up a PàF government.

Seventh, the PS leadership's mistrust of the PCP ever since the latter's protohegemonic drive during the 'Hot Summer' (Verão Quente) of Portugual's transition to democracy, was raised during the discussions in 2015. However, the new and more left-wing generation that stood behind António Costa had no memory of these events, meaning the absence of this 'genetic trauma' may have helped both sides psychologically to reach an agreement (FREIRE, 2017).

A new 'red-green' party appeared during the 2015 election campaign'. 'Livre' (Free) formed an electoral pact with a breakaway faction from the BE to form 'Livre-Tempo de Avançar' (Free-Time to Move Forward) which sought to fill the gap on the left by putting a great deal of effort into reaching agreements between all Portuguese left-wing parties (FREIRE and LISI, 2016a; LIVRE, 2015, 2013). The appearance of this new party, its 2015 electoral pact and the emphasis it placed on the need for left-left co-operation can also be considered one of the factors that

\footnotetext{
${ }^{9} \mathrm{~A}$ radical left party formed in 2014 by former BE deputy Rui Tavares, which ran for the first time at the 2014 European elections, where it obtained $2.2 \%$ of the vote. Like the BE, it can be considered a left-libertarian party and is a member of the Green Party bloc at the EU level.
} 
pushed the parties of the radical left, and especially the BE, to co-operate with the PS from late 2015 (LISI, 2016, pp. 541-560).

\section{The process of government formation}

Portugal's 21st constitutional government was unique for four main reasons. The first is the novelty of left-wing co-operation (COSTA, 2016, 2015). The second concerns the process of government formation: specifically, this was the first time the party with the most parliamentary seats had not formed or even been part of the subsequent government. With regard to the third reason, it is worth remembering that Portugal has a semi-presidential system of government, which gives the president significant constitutional powers (AMORIM NETO and LOBO, 2009, pp. 234-255). However, since the 1982 constitutional reform, the executive answers to the parliament and not to the president, which is why the president can only dismiss the government if the 'normal functioning of democratic institutions' is at risk. Where the President can exercise power with fewer political restrictions is in matters concerning the dissolution of parliament and the ability to call early general elections. While the president may have more freedom in this respect however, there are the limitations already mentioned in the previous section. The then- President, from the PSD, Cavaco Silva expressed doubts about the post-electoral 'left front' for two main reasons (because the radical left might call into question Portugal's international alliances with the EU and NATO, and because the PàF coalition - and not the PS - won most votes and seats) (SILVA, 2015a; 2015b). However, at the end of a complicated process of government formation (CRUZ, 2015), the president was forced to accept the post-electoral 'left front' (CRUZ, 2015; SILVA, 2015b).

The fourth main reason why the 21st constitutional government should be considered innovative concerns the PS' policy aims and the fundamental shift of the political spectrum as a result of the political solution reached: the 'policy contamination' of the PS by the radical left. Whenever the PS had won a general election without a majority (which was every victory it had since 1976 with the exception of 2005), it had relied on support from the right (either from the PSD or CDS-PP), whether in the shape of a formal coalition or a less formal parliamentary support agreement, in order to survive in parliament and to pass important 
legislation (including its budgets). This had meant a rightward bias in the political system in terms of policy orientations (MARCH and FREIRE, 2012). For example, data from a number of surveys conducted at different times (2004, 2009 and 2014) asking voters to place parties on a left-right scale have consistently shown that the PS was (and remains) one of the least left-wing social democratic parties in Europe (MARCH and FREIRE, 2012).

\section{The flagship measures of the new political alliance}

The mandate of the right-wing coalition during the Troika years of 2011-15 was marked by a strong neoliberal orientation that went far beyond the requirements of the bailout MoU (FINN, 2017, pp. 05-32; FREIRE, 2016, pp. 173193). This included wage cuts for public sector employees, cuts to pensions, public sector employment cuts and reductions in state benefits as well as extensive privatisations that went far beyond anything contained in the 2011 MoU. Many of the measures introduced were even contrary to the electoral commitments adopted by the winners of the 2011 election (FREIRE, 2016, pp. 173-193). The neoliberal policies introduced by the government during this period was one of the main reasons why the parties of the left were able to reach a compromis e - so they could reverse these decisions (CRUZ, 2015).

Some of the flagship measures taken by the left-wing governmental alliance, which show both a change in the socialists' policy orientations vis-à-vis neoliberal austerity guidelines and a significant influence of the radical left parties in the shifts made by the socialists, include the following (COSTA, 2015; CRUZ, 2015; LUÍS and GARCIA, 2015, pp. 39-44): 01. Raising the minimum wage in 2016 and 2017; 02. reversing public sector wage cuts, which the PS had planned to do over two years (2016-17), but which was completed by 2016; 03. unfreezing pensions immediately in 2016 (the PS had planned to keep them frozen); 04. removing measures proposed in the PS manifesto to make it easier for employers to make workers voluntarily redundant (despedimento conciliatório) (PARTIDO SOCIALISTA, 2015); 05. removing measures proposed in the PS manifesto (PS, 2015) to reduce the amount paid by employees in social transfers (these measures were proposed only for low-income workers). While this was removed at the insistence of the BE and PCP, the PS' plans to retrieve these 
'social adjustment' measure (now the amount paid by employers in social transfers, by number of workers) as an exchange currency to raise the minimum salary created tensions between the PS and the parties to its left in 2017 (CAMPOS, 2017; LIMA and ALMEIDA, 2017; TIAGO, 2016); 06. reversing reductions to corporate tax implemented in 2013-14 with the PS' approval; 07. restoring the 35-hour working week for civil servants ${ }^{10}$; 08 . the restoration, in 2016, of the four public holidays that had been suspended by the PSD/CDS-PP government during the Troika years; 09. halting all further privatisations and reversing some of those that were underway (e.g. TAP Air Portugal, local authority public transport systems and water supplies); 10. increasing investment in public services (social security, education, health) and bringing them back up to pre-Troika standards, ending the outsourcing of public sector work to the private sector; and 11. the introduction of strict limits on the ability of lenders to evict people from their homes for falling behind on their mortgages in certain circumstances (e.g. loss of job or financial difficulties).

\section{The major political and socioeconomic policies of the 2015-2019 left-wing alliance}

Portugal's left-wing government alliance performed rather well in several policy areas over 2015-2019, particularly in four key areas. Despite the normal internal tensions, the government has proved to be remarkably stable in political terms and completed its full term. It also reversed the austerity implemented during the years 2011-2014, increasing domestic demand by restoring people's social rights and income levels and investing more in public services (education and health), suggesting there was renewal and rejuvenation of the Socialist Party under radical left influence. Third, contrary to the expectations of some mainstream journalists, senior EU officials and right-wing politicians, the reversal of austerity patterns has resulted in improved economic performance (with increased economic

\footnotetext{
${ }^{10}$ This measure was finally passed by parliament on 2 June 2016 and shortly thereafter approved by the president and implemented on 1 July 2016. Although the measure is important in that it reestablishes the pre-Troika status quo, which was a central part of the agreements between the PS and the parties of the radical left as a means of combatting unequal austerity, the truth is that the measure is very limited in its scope and excludes public sector employees with individual contracts, which accounts for a large proportion of civil servants recruited since 2000 (i.e. public sector employees with individual contracts). Thus, not only does the measure not apply to private sector employees, it also excludes many in the public sector. If a more progressive approach to working hours is something that the post-election left front wants and considers feasible, then further measures will be needed.
} 
growth and lower unemployment). Of course, the relative contribution of the government's domestic policies, the reforms implemented by the previous government and the general improvement in the international economy to these positive economic outputs remain to be scrutinized.

There were also positive financial results, including reductions in the national deficit and public debt, with Portugal remaining in full compliance with EU rules (FERREIRA et al., 2017) ${ }^{11}$. All these positive outcomes helped ensuring that the government remained politically stable, while also raising the stakes for those who might wish to break the alliance (FERREIRA et al., 2017), and increasing popular support for the government.

Overall, this left-left alliance has pushed the PS further to the left on the leftright spectrum, thus reversing the right-wing bias in Portuguese politics (FINN, 2017; FREIRE, 2017). As such, even if the government and the parties of the radical left supporting it maintained some level of austerity and were fiscally conservative in an attempt to stay within EU rules (to a greater extent than they had intended), the truth is that the shift from an asymmetrical pattern of austerity to one that is more balanced and equitably distributed between capital and labour ('tempered austerity'), is in no way irrelevant. Indeed, it is of critical importance because this is the way to restore some of the balance between capital and labour that the rightwing parties tried to undermine during the Troika years.

Thinking about the OVERALL PERFORMANCE of the 2015-2019 Socialist government, which was supported in parliament by the BE and PCP-PEV, how would you rate this government's efforts? Would you say it has done a very good job, a good job, a bad job or a very bad job?

Unlike the stance adopted by its critics, the Portuguese electorate that voted for the parties of the Left, and those who are sympathetic to it, believe the government did a good job. According to data gathered via a panel survey 2016-18) carried out between May and June 2016 ${ }^{12}$, there was broad support for the government's actions (Table 04) and performance (Table 05).

\footnotetext{
${ }^{11}$ See Ferreira et al., (2017) for the relevant economic and financial data.

${ }^{12} \mathrm{This}$ is an internet panel and therefore a sample that underrepresents those at the lower end of the economic scale. That is why we weighted the data by level of education to correct for this distortion for the adult population living in mainland Portugal.
} 
As with the right-wing parties in Portugal, have the left-wing parties (PS, BE and PCP/PEV) done well by reaching an agreement to govern?

Table 04. Attitudes of Portuguese voters vis-à-vis the centre-left and radical left (supported) government, April-June 2016, by party preference (\% of the total in each group)

\begin{tabular}{llllllll} 
& \multicolumn{7}{c}{ Voter party sympathy } \\
\cline { 2 - 9 } & BE & PCP-PEV & PS & PSD & CDS-PP & $\begin{array}{l}\text { Without party } \\
\text { sympathy }\end{array}$ & Total \\
\cline { 2 - 8 } Totally disagree & 0,5 & 0,6 & 0,5 & 39,6 & 29,6 & 6,5 & 9,9 \\
Disagree & 9,1 & 4,7 & 4,2 & 19,6 & 22,2 & 13,9 & 12,4 \\
Neither disagree, nor agree & 13,9 & 19,9 & 13,1 & 22,3 & 29,6 & 37,4 & 28,4 \\
Agree & 35,8 & 39,8 & 49,9 & 15,8 & 17,3 & 31,3 & 32,6 \\
Totally agree & 40,6 & 35,1 & 32,3 & 2,6 & 1,2 & 10,9 & 16,8 \\
N (100\%) & 187 & 171 & 450 & 341 & 81 & 1408 & 2650 \\
\hline
\end{tabular}

Source: Data calculated by the author from Freire, Lisi and Tsatsanis (2016a). Data weighted by level of education.

Table 05. Attitudes of the Portuguese vis-à-vis the centre-left and radical left (supported) government's general performance, April-June 2016, by party sympathy ( $\%$ of the total in each group)

\begin{tabular}{llllllll}
\hline & \multicolumn{7}{c}{ Voters' party sympathy } \\
\cline { 2 - 8 } & BE & PCP-PEV & PS & PSD & CDS-PP & $\begin{array}{l}\text { Without party } \\
\text { sympathy }\end{array}$ & Total \\
\cline { 2 - 8 } Very bad & 2,1 & 5,3 & 2,7 & 22,9 & 15,0 & 8,5 & 9,0 \\
Bad & 14,4 & 10,5 & 5,4 & 41,6 & 55,0 & 38,8 & 30,8 \\
Good & 71,8 & 78,4 & 79,8 & 34,6 & 30,0 & 50,9 & 56,0 \\
Very good & 11,7 & 5,8 & 12,1 & 0,9 & 0,0 & 1,7 & 4,2 \\
N (100\%) & 188 & 171 & 406 & 341 & 80 & 1408 & 2651 \\
\hline
\end{tabular}

Source: Data computed by the author from Freire, Lisi and Tsatsanis (2016a). Weighted data by education.

\section{Epilogue: the general election of 06 October 2019 and the new government in} Portugal

In terms of empirical data and focus, the present article is about the leftwing alliance for government between late 2015 and late 2019. However, following the general election of 06 October 2019 we thought it appropriate to include a very general epilogue about these recent changes.

The agreements between the four parties (PS, BE and PCP-PEV) signed in November 2015 were a requirement of the then-president, and effectively underpinned the remarkable stability that characterised the 13th legislature. The agreements, which covered issues of governance (motions of censure and trust), also guaranteed political-ideological coherence by ensuring a government that was aligned to the Left. Of course, many matters were not included in the agreements (in particular those dealing with Europe and issues related to political- 
military alignments, as well as, for example, labour laws and support for the financial sector). On these issues the PS minority government relied mainly on support from the right (or at least their abstention) to ensure the measures passed. Overall, the 'geringonça' (contraption) government, as it was often called in Portuguese mass media, had positive outcomes in both political and socioeconomic terms, and, as already mentioned, always complied with EU financial rules.

The result of the elections of 06 October brought the 'geringonça' government to an end. By winning with 36.7 per cent of the vote share and electing 108 MPs (46.9 per cent of the total), arithmetically speaking, the PS required only one of the two other parties that supported had the 'geringonça' (the BE with 19 MPs or the PCP-PEV with 12 MPs) to secure a parliamentary majority. On the other hand, the PS could have established an 'oversized alliance' (one that would have given it a large parliamentary majority) including all the parties that had formed the 'geringonça', and even expanded it to include other non-right wing parties, such as 'Livre' and 'Animais-Pessoas-Natureza' (Animals-PeopleNature, PAN). However, this solution was made unfeasible by the unwillingness of both the PCP-PEV and PAN to enter into a written agreement, and by 'Livre' insisting on a multilateral agreement with all parties of the Left before it would enter into any alliance. The PS was left with the option of a written agreement with BE, which it was willing to sign; however, the PS did not want an agreement with just one other party. This means it is likely that Portugal will end up with a minority PS government that seeks support from the Left on some issues and from the right on others (in Portugal this is called 'piscando', or 'winking'), although the PS says its preference is to negotiate with the parties of the Left. At the time of writing, in early 2020, the PS has indeed been following that approach, for example in the 2020 budget negotiations. The budget was approved with favourable votes from the PS, the abstention of the radical left parties (BE, PCP-PEV, PAN and Livre), and against opposition from the right-wing parties. The Socialists had to made significant concessions to the radical left to achieve this outcome. 


\section{Conclusions}

Since the democratic transition of 1974-76, parties of the radical left in Portugal have played an important role in the political system, both at the institutional level and in terms of mobilisation, as Anna Bosco long ago pointed out (BOSCO, 2001). However, until late 2015, they had never been formally integrated at the level of government. After several years of neoliberal measures and four years of right-wing government (2011-2015), anti-austerity discourse gained strength within the electorate. However, considering the centre-right coalition won the 2015 general election, albeit only with a plurality and not a majority, we should be cautious when speaking of the success of the radical-left. Looking at the 2015 result, it is worth noting that the radical left's share was very similar to that it had obtained in the 2009 general election, which took place at the beginning of the economic crisis. This suggests not much has changed at the level of political discourse and that the radical left's message has had relatively little success with the electorate. This means that the 2015 result perhaps had more to do with dissatisfaction with the incumbents than a desire for creating new alternative solutions and experimenting with new government practices.

One of the reasons for this may have been the pressure being exerted by the EU and the example of Greece (with the radical left Syriza leading both the government and an anti-austerity front with the nationalists Independent Greeks, 2015-2019, obliged to comply with further austerity measures after a popular referendum had clearly rejected them), which limited the options for credible alternatives. From this viewpoint, not only did the electorate remain strongly in favour of the country remaining in the Eurozone, but there are also clear signs that no radical changes are in fact possible, and that the only possible route is via moderate and gradual reforms. Moreover, the failure of the parties of the radical left to influence political discourse may also be explained by the widespread 'TINA' (There Is No Alternative) approach adopted by the Portuguese media.

During the 2015 election campaign new actors like 'Livre' / 'Tempo de Avançar' seemed to have deepened the problems facing the radical left in Portugal, by highlighting the need for broad alliances on the Left in order to get into government (i.e. including the Socialists and the radical left), which were mainly impeded by a lack of co-operation (among the radical left parties and especially with 
the PS) and their marginal position at the institutional level. However, there were some small signs that pointed in the opposite direction: e.g. the declared unwillingness of the PS leader to form a coalition with the Right; the BE's pragmatic suggestion to form a coalition with the PS, proposed during a TV debate between Costa and the leader of the BE, Catarina Martins, on 14 September 2015; and the similar willingness of the PCP to enter into talks with the PS, as stated in their offer on 23 August 2015. From this viewpoint, it is a case of 'old challenges, new responses' (FREIRE and LISI, 2016a). Prior to the 2015 elections there seemed to be no significant move either in terms of policy proposals or strategic orientations that could bring the parties of the Left closer in order to create an alternative government to that being offered by the right-wing PàF coalition. However, somewhat surprisingly, the result of the 2015 legislative elections left the right as the largest single group in parliament (i.e. with a plurality), but without a majority. This was like the Berlin Wall finally falling in Portugal 26 years after the events of 1989.

The 21st constitutional government was a left-left government in which a PS minority cabinet governed alone with support in parliament from the BE, PCP and PEV. Against all expectations (particularly given the position of the mainstream media, senior EU officials, the right-wing political parties and the former president, Cavaco Silva) the 21st government performed pretty well on several counts, in both political and policy terms. This was particularly the case with regard to political stability (a full term was completed), the reversal of Troika-era austerity with increases in employment, social rights and benefits for workers and retired people, higher investment in public services and a boost to domestic demand, and the fact that these positive economic and financial outcomes were all achieved while maintaing full compliance with EU norms. These positive results enhanced the political stability of and popular support for both the government and the left-wing parties, which in turn received great public interest and attention at both the domestic and the international levels.

Considering our four research questions (the main question, plus three further questions derived from the first), we arrived at the following findings. First, we showed that, along with other factors (namely, the significant shift of centreright parties to the neoliberal right in terms of policy orientations, Mr. António 
Costa's leadership of the PS being at stake, the generational change within the PS that allowed it to overcome historical distrust vis-à-vis the radical left, and the new parties pressing the radical left for an alliance), in the Portuguese case the crisis did have an impact in changing the patterns of governmental alliances on the Left. Second, we argue that these changes in coalitional politics, plus the articulation of left-wing parties with the new social movements in fighting austerity during the Troika intervention (ESTANQUE et al., 2017; FERNANDES, 2017), are important routes for renewal and rejuvenation of social democracy in Portugal as elsewhere. Both the radical left and the old (unions) and new social movements have had an important role fighting austerity during the crisis, and thus can push social democratic parties away from the neoliberal consensus, as was the case in Portugal in contrast to what has occurred in other European countries (LAVELLE, 2014; MERKEL, 2011). Third, we showed several changes in the Socialists' (PS) policy orientations in Portugal, namely by contesting pro-austerity positions and reversing many Troika measures enforced by the right-wing government (2011-2015), even if they were conservative in fiscal terms in complying with EU rules, contrary to what occurred in other European countries (BAILEY et al., 2014a; LAVELLE, 2014). Finally, we showed that all of these changes demonstrated an increased influence of the radical left parties, although afterwards, in electoral terms (October 06, 2019, national elections), the Socialists (PS) have benefited the most (with far more seats and votes and winning a plurality in 2019), the Left Bloc (BE) maintained the same number of MPs and suffered only a slight decline in the number of votes, and the Communists (PCP-PEV) declined significantly in terms of both MPs and votes. However, since the evaluations of the governmental alliance have been very positive among the constituents of all the left-wing parties (PS, BE, PCP-PEV) ${ }^{13}$, we can hardly say that the alliance is responsible for the Communist electoral decline.

Some might see a contradiction in arguing that the Portuguese experience may have strengthened the position of the social democratic left, while,

\footnotetext{
${ }^{13}$ See for example the mass survey results in Pereira (2019), 'PS fica longe de maioria absoluta, PSD chega aos 30\%', Público, 02-10-2019, pp. 03-05; 'Portugueses querem governo PS e Bloco de Esquerda', Público, 24-07-2019. Dinis (2019), 'PS sem maioria mantem três aliados à mão', Expresso, 04-10-2019, pp. 03-07. 'Público' is a Portuguese daily newspaper, 'Expresso' is a Portuguese weekly newspaper.
} 
simultaneously, increasing the influence of the radical left. This is because the 2019 general election result points towards a more modest assessment of the radical left's electoral performance. In fact, only the socialists (PS) increased their electoral result 2015-2019. However, the Left Bloc (BE) maintained its electoral performance while significantly increasing its influence over Socialist policymaking. The case of the Communists (PCP and PEV) is more complicated because they saw their electoral and parliamentary performance decline, even though, as we just explained, this decline can hardly be attributed to their participation in the government. More importantly, and like the BE, the PCP-PEV alliance, but especially the PCP, significantly increased their influence over the Socialists' policies. Thus, overall, this apparent contradiction would suggest a sort of positive-sum in Portuguese leftwing inter-party competition, which may be an interesting lesson to draw from the Portuguese case. However, this finding would need further development in future research.

Three fundamental implications can be envisaged at the European level. First, will this major change in Portugal have a contagious effect in other European countries? If the answer is yes, can those changes contribute to changing the neoliberal status quo in the EU? This is something that is yet to be seen. Can this new pattern of alliances between the centre left and the radical left, instead of grand coalitions of the centre left with the centre right or other types of rainbow alliances, offer some inspiration to the European Left (both social democratic and radical left parties) and help arrest the decline of social democratic parties? It has certainly resulted in some inspiration for the European Left and it can help reverse the rightward and neoliberal drift of social democratic parties, although the outcome of this is yet to be determined. In Spain, since January 2020, a new progressive government coalition, bringing together the socialists (PSOE) and the radical left ('Unidas Podemos'), is already pointing in this direction.

Domestically, the 21st constitutional government introduced at least three major innovations. The first was in terms of the character of the government and patterns of co-operation on the Left (centre left minority government with the formal support of the radical left): no constitutional government prior to late 2015 had had such a character. Since it was pretty stable and able to deliver, this new 
political solution has the potential to open a new chapter in Portuguese politics - a new era of greater inclusiveness and responsibility. The second major innovation relates to the process of government formation. This was the first time in Portugal in which the winning party did not end up forming, or even participating in, the government. Third, in terms of the PS' policy orientations, and the wider effects on the political system resulting from this political solution, the PS was 'contaminated' by the radical left. Overall, this post-electoral 'left front' alliance meant the PS was 'forced' to move further to the left on the left-right spectrum, challenging the rightwing bias in Portuguese politics. Ultimately, if it proves durable, this new pattern of coalitional politics may bring about a fundamental change in Portuguese politics, reversing the historical right-wing bias. Again, if followed elsewhere, this could have significant implications in Europe - new coalitional politics on the Left have the potential to reverse the neoliberalisation of social democracy resulting from permanent alliances with the right/centre-right, either in office and/or in terms of policy direction. Although the impact of the Portuguese example on the wider European stage is yet to be seen, the example is there to be emulated. In fact, some data shows the Portuguese solution was being increasingly viewed as a source of inspiration by social democrats across Western Europe (AMES, 2017).

Revised by Fraser Robinson Submitted on June 23, 2019

Accepted on June 01, 2020

\section{References}

ALONSO, Sonia (2014), You can vote but you cannot choose: democracy and the sovereign debt crisis in the Eurozone. Working Paper. Instituto Mixto Universidad Carlos III de Madrid. Madrid: Fundación Juan March de Ciencias Sociales.

AMES, Paul (2017), European left wants piece of Portugal's contraption. Político. Available at <https://www.politico.eu/article/antonio-costa-pssocialists-european-left-wants-piece-of-portugal-contraption/>. Accessed on December 21, 2018.

AMORIM NETO, Octávio and LOBO, Marina Costa (2009), Portugal's semipresidentialism (re)considered: an assessment of the president's role in the policy process, 1976-2006. European Journal of Political Research. Vol. 04, № 25, pp. 234-255. 
BACALHAU, Mário (1994), Atitudes, opiniões e comportamentos políticos dos portugueses: 1973-1993. Lisboa: Ed. Mário Bacalhau and Thomas Bruneau. 134 pp..

BACALHAU, Mário (1987), Sondagem de opinião política. Lisboa: ESEO. (policopiado).

BAILEY, David; DE WAELE, Jean-Michel; ESCALONA, Fabien, and VIEIRA, Mathieu (2014), European social democracy during the global economic crisis: renovation or resignation? Manchester: Manchester University Press. 304 pp..

BAILEY, David; DE WAELE, Jean-Michel; ESCALONA, Fabien, and VIEIRA, Mathieu (ed) (2014), Introduction. In: European social democracy during the global economic crisis: renovation or resignation? Manchester: Manchester University Press. pp. 01-03.

BALE, Tim and DUNPHY, Richard (2012), De parias à participants. In: Les parties de la gauche anticapitaliste en Europe. Edited by DE WAELE, Jean-Michel and SEILER, Daniel-Louis. Paris: Economica. pp. 32-49.

BALE, Tim and DUNPHY, Richard (2011), In from the cold: left parties and government involvement since 1989. Comparative European Politics. Vol. 09, № 03, pp. 269-291.

BARTELS, Larry and BERMEO, Nancy (2014), Mass politics in tough times: opinions, votes and protest in the Great Recession. Oxford: Oxford University Press. 396 pp..

BARRETO, António; FREIRE, André; LOBO, Marina Costa, and MAGALHÃES, Pedro (2003), As eleições legislativas de 2002 - Inquérito pós-eleitoral, 2002. Arquivo Português de Informação Social, Lisboa. APIS0005. Available at <http://hdl.handle.net/10400.20/27 >. Accessed on July, 14, 2020.

BELCHIOR, Ana Maria; SILVA, Sofia Serra da, and QUEIROGA, Viriato (2014), Panel survey to the Portuguese population - First wave, Project 'Public Preferences and Policy Decision-Making. A Longitudinal and Comparative Analysis', PTDC/IVC-CPO/3921/2012, CIES-IUL and ISCTE -IUL - Instituto Universitário de Lisboa.

BENOIT, Kenneth and MICHAEL, Laver (2006), Party policy in modern democracies. London: Routledge. 300 pp..

BLOCO DE ESQUERDA (2015a), Resolução aprovada na VIII do Bloco de Esquerda 2011: a esquerda contra a dívida. Lisbon: BE.

BLOCO DE ESQUERDA (2015b), Recuperar o que é nosso: Manifesto Eleitoral Legislativas 2015. Lisbon: BE. 
BLOCO DE ESQUERDA (2013), Declaração da Comissão Política do Bloco de Esquerda. Lisbon: BE.

BLOCO DE ESQUERDA (2011), Compromisso eleitoral: Bloco de Esquerda 2011 Mudar de Futuro, Pelo Emprego e Pela Justiça Fiscal. Lisbon: BE.

BLYTH, Mark (2012), Austerity: the history of a dangerous idea. Oxford: Oxford University Press. 336 pp..

BOSCO, Anna (2001), Four actors in search of a role: the Southern European Communist Parties. In: Parties, politics, and democracy in the New Southern Europe. Edited by: DIAMANDOUROS, Nikiforos and GUNTHER, Richard. Baltimore: The Johns Hopkins University Press. pp. 329-387.

BUDGE, Ian; KLINGEMANN, Hans-Dieter; VOLKENS, Andrea; BARA, Judith, and TANENBAUM, Eric (2001), Mapping policy preferences: estimates for parties, electors, and governments 1945-1998. Oxford: Oxford University Press. 388 pp..

CAMPOS, António Correia (2017), Correia de Campos dá razão aos sindicatos nas críticas à descida da TSU. Público, January, 12, 2017. Available at <https://www.publico.pt/2017/01/12/economia/entrevista/correiade-campos-da-razao-aos-sindicatos-nas-criticas-a-descida-da-tsu1757948>. Accessed on August, 03, 2020.

COSTa, António (2016), Ano novo, tempo novo. Diário de Notícias. Available at <www.dn.pt/opiniao/opiniao-dn/convidados/interior/ano-novotempo-novo-4961117.html >. Accessed on December, 21, 2018.

COSTA, António (2015), Discurso de tomada de posse do Primeiro-Ministro, António Costa. November, 22, 2015. Available at <https://ps.pt/index.php/2015/11/26/discurso-de-tomada-de-posse-doprimeiro-ministro-antonio-costa/> Accessed on December, 21, 2018.

CRUZ, Vanessa (2015), Oficial: Acordos à esquerda assinados. Available at <https://tvi24.iol.pt/politica/10-11-2015/oficial-acordos-a-esquerdaassinados $>$. Accessed on December, 21, 2018.

DE GIORGI, Elisabetta and SANTANA-PEREIRA, José (2016), The 2015 Portuguese election: widening the coalition space and bringing the extreme left. South European Society and Politics. Vol. 21, № 04, pp. 451-468.

DE GIORGI, Elisabetta; MOURY, Catherine, and RUIVO, João Pedro (2015), Governing Portugal in hard times: incumbents, opposition and international lenders. Journal of Legislative Studies. Vol. 21, № 01, pp. 54-74.

DINIS, David (2019), PS sem maioria mantem três aliados à mão. Expresso. Available at shttps://expresso.pt/legislativas-2019/2019-10-03-Sondagem.PS-sem-maioria-mantem-tres-aliados-a-mao . Accessed on November, 19, 2020. 
DUNPHY, Richard and BALE, Tim (2011), The radical left in coalition government: towards a comparative measure of success and failure. Party Politics. Vol. 17, № 04, pp. 488-504.

ESTANQUE, Elísio; COSTA, Hermes Augusto, and FONSECA, Dora (2017), Building the 'contraption': anti-austerity movements and political alternative in Portugal. In: Challenging austerity: radical left and social movements in the South of Europe. Edited by ROCA, Beltrán; MARTÍN-DÍAZ, Emma, and DÍAZPARRA, Ibán. London: Routledge. pp. 111-133.

EUROPEAN ELECTION STUDY (1999), International Research Group European Election Studies. IPSOS, Hamburg, Germany. Available at <http://dx.doi.org/10.17026/dans-z9j-vy6m>. Accessed on July, 14, 2020.

FERNANDES, Tiago (2017), Late neoliberalism and its discontents: the case of Portugal. In: Late neoliberalism and its discontents in the economic crisis comparing social movements in the European periphery. Edited by DELLA PORTA, Donatella; ANDRETTA, Massimiliano; FERNANDES, Tiago; O'CONNOR, Francis; ROMANOS, Eduardo, and VOGIATZOGLOU, Markos. New York: Palgrave Macmillan. pp. 169-200.

FERREIRA, Ana Rita; STETTER, Ernst; PEREIRA, Pedro Silva; MENDES, Ana Catarina; SANTOS, Pedro Nuno; ALBUQUERQUE, João; DÂMASO, Mafalda, and FREITAS, Maria (2017), The Portuguese government solution: the fourth way to socialdemocratic politics? Brussels and Lisbon: Foundation for European Progressive Studies and Fundação Res Publica.

FINN, Daniel (2017), Luso-anomalies. New Left Review. Vol. 106, pp. 05-32.

FREIRE, André (2017), Para lá da 'geringonça': O governo de esquerdas em Portugal e na Europa. Lisbon: Contraponto. 232 pp..

FREIRE, André (2016), The condition of Portuguese democracy during the Troika's intervention, 2011-2015. Portuguese Journal of Social Science. Vol. 15, № 02, pp. 173-193.

FREIRE, André; and LISI, Marco (2016a), The Portuguese radical-left and the Great Recession: old challenges and new responses. In: Europe's radical-left: from marginality to mainstream? Edited by MARCH, Luke and KEITH, Daniel. London: Rowman and Littlefield. Pp. 253-272.

FREIRE, André and LISI, Marco (2016b), Introduction: political parties, institutions and civil society - the economic crisis and the evolution of Southern Europe political systems. Portuguese Journal of Social Science. Vol. 15, № 02, pp. 153171. 
FREIRE, André; LISI, Marco, and LIMA, Inês (2015), Crise económica, política de austeridade e o potencial de coligação da 'esquerda radical' portuguesa. In: Crise económica, políticas de austeridade e representação política. Edited by FREIRE, André; LISI, Marco, and VIEGAS, José Manuel Leite. Lisbon: Assembleia da República. pp. 385-410.

FREIRE, André; LISI, Marco, and TSATSANIS, Emmanouil (2016a), Portuguese citizens survey 2016-2018, research project at CIES-IUL and IPRI-NOVA, 'Crisis, political representation and democratic renewal: the Portuguese case in the Southern European context'. FCT: PTDC/IVC-CPO/3098/2014. Available at $<$ http://er.cies.iscte-iul.pt/> Accessed on July, 14, 2020.

FREIRE, André; LISI, Marco and VIEGAS, José Manuel Leite (2015), A gestão política das crises, os mandatos dos governos e a representação política. In: Crise económica, políticas de austeridade e representação política. Edited by FREIRE, André; LISI, Marco, and VIEGAS, José Manuel Leite. Lisbon: Assembleia da República. pp. 19-48.

FREIRE, André; VIEGAS, José Manuel Leite, and LISI, Marco (2012), «Inquérito aos Cidadãos Portugueses 2012», Projeto de Investigação do ISCTE-IUL e do CIESIUL, «Eleições, liderança e responsabilização: a representação política em Portugal numa perspetiva longitudinal e comparativa». FCT: PTDC/CPJCPO/119307/2010. Available at <http://er.cies.iscte-iul.pt/> Accessed on July, $14,2020$.

FREIRE, André; VIEGAS, José Manuel Leite, and SEICEIRA, Filipa (2009), Representação política em Portugal: inquéritos e bases de dados. Lisboa: Sextante. 230 pp..

HOOGHE, Liesbet; BAKKER, Ryan; BRIGEVICH, Anna; DE VRIES, Catherine; EDWARDS, Erica; MARKS, Gary; ROVNY, Jan; STEENBERGEN, Marco, and VACHUDOVA, Milada (2010), Reliability and validity of the 2002 and 2006 chapel hill expert surveys on party positioning. European Journal of Political Research. Vol. 49, № 05, pp. 687-703.

KEITH, Daniel and CHARALAMBOUS, Giorgos (2016), On the (non) distinctiveness of Marxism-Leninism: the Portuguese and Greek communist parties compared. Communist and Post-Communist Studies. Vol. 49, № 02, pp. 147-161.

KLINGEMANN, Hans-Dieter; VOLKENS, Andrea; BARA, Judith; BUDGE, Ian, and MCDONALD, Michael D. (2006), Mapping policy preferences II: estimates for parties, electors and governments in Eastern Europe. European Union and OECD 1990-2003. Oxford: Oxford University Press. 292 pp..

LAVELLE, Ashley (2014), Postace: death by a thousand cuts. In: European social democracy during the global economic crisis: renovation or resignation? Edited by BAILEY, David; DE WAELE, Jean-Michel; ESCALONA, Fabien, and VIEIRA, Mathieu. Manchester: Manchester University Press. pp. 270-284. 
LAVELLE, Ashley (2008) The death of social democracy: political consequences in the 21st Century. Aldershot: Ashgate Publishing. 221 pp..

LIMA, Maria P. C. and ALMEIDA, João R. (2017), Uma balança só funciona com pratos equilibrados. Público. Available at <https://www.publico.pt/2017/01/11/politica/opiniao/uma-balancaso-funciona-com-pratos-equilibrados-1757769>. Accessed on November, $19,2020$.

LISI, Marco (2016), U-turn: the Portuguese radical-left from marginality to government support. South European Society and Politics. Vol. 21, № 04, pp. 541-560.

LIVRE-TEMPO DE AVANÇAR, (2015), Programa eleitoral eleições legislativas de 2015: livre de lutar, livre para governar, é tempo de avançar. Lisbon: L-TODA. Available at <www.tempodeavancar.net/wpContent/uploads/2015/09/programa_final_convencao_20_09_15_versao _site_6.pdf>. Accessed on December, 21, 2018.

LIVRE (2013), Roteiro para a convergência: versão preliminar de 23 de Novembro de 2013. Available at <livrept.net/wp-content/uploads/2014/05/roteiro-para-aconvergencia.pdf>. Accessed on December, 21, 2018.

LOBO, Marina Costa and MAGALHÃES, Pedro (2019), Estudo eleitoral Português 2011. Arquivo Português de informação social, Lisboa. APIS0043. Available at <http://hdl.handle.net/10400.20/2059>. Accessed on July, 14, 2020.

LOBO, Marina Costa; MAGALHÃES, Pedro, and GASPAR, João Tiago (2019), Estudo eleitoral Português 2015. Arquivo Português de informação social, Lisboa. APIS0040. Available at <http://hdl.handle.net/10400.20/2056>. Accessed on July, 14, 2020.

LOBO, Marina Costa; MAGALHÃES, Pedro; BARRETO, António, and FREIRE, André, (2019), Estudo Eleitoral Português 2005. Arquivo Português de informação social, Lisboa. APIS0042. Available at <http://hdl.handle.net/10400.20/2058>. Accessed on July, 14, 2020.

LUÍS, Filipe and GARCIA, João (2015), António Costa: 'Até o Schauble está tranquilo' - 'Grau de convergência com Bloco e PCP não foi suficiente para que integrassem o governo'. Visão. Vol. 12, pp. 39-44.

MARCH, Luke (2011), Radical-left parties in contemporary Europe. Abingdon: Routledge. 275 pp..

MARCH, Luke (2008), Contemporary far left parties in Europe: from Marxism to the mainstream? Berlin/Bonn: Friedrich Ebert Stiftung. 24 pp.. 
MARCH Luke and FREIRE André (2012), A esquerda radical em Portugal e na Europa: Marxismo, mainstream ou marginalidade? Porto: Quidnovi. 288 pp..

MARCH, Luke and KEITH, Daniel (2016), Europe's radical-left: from marginality to mainstream? London: Rowman and Littlefield. 466 pp..

MATTHIJS, Matthias (2014), Mediterranean Blues: the crisis in Southern Europe. Journal of Democracy. Vol. 25, № 01. pp. 101-115.

MAVROGORDATOS, George. Th.; NICOLACOPOLOUS, Ilias; TSOUCALAS, Constantine; GUIDOROSSI, Giovanna; URBANI, Giuliani; MANNHEIMER, Renato; WEBER, Maria; MORLINO, Leonardo; BACALHAU, Mário; STOCK, Maria José; CONDE, Rosa; MARTINEZ, Usbaldo; MONTERO, José Ramón; SANI, Giacomo, and SANTAMARIA, Julian (1991), The political culture of Southern Europe: a four nation study. GESIS Data Archive, Cologne. ZA2008 Data file Version 1.0.0. Available at <https://doi.org/10.4232/1.2008> Accessed on July, 14, 2020.

MERKEL, Wolfgang; PETRING, Alexander; HENKES, Christian, and EGLE Christoph (2011), Social democracy in power: the capacity to reform. London: Routledge. 328 pp..

PARTIDO COMUNISTA PORTUGUÊS (2011), Compromisso por Uma Política Patriótica e de Esquerda: Legislativas de 2011. Lisbon: PCP.

PARTIDO COMUNISTA PORTUGUES (2015), Política Patriótica e de Esquerda: Soluções para um Portugal com Futuro. Lisbon: PCP.

PARTIDO SOCIALISTA (2015), Programa eleitoral do Partido Socialista: legislativas de 2015. Lisbon: PS.

PEREIRA, Helena (2019), PS fica longe de maioria absoluta, PSD chega aos 30\%. Público. Available at $\leq$ https://www.publico.pt/2019/10/01/politica/noticia/pslonge-maioria-absoluta-psd-chega-30-1888500 $\geq$. Accessed on November, 19, 2020.

ROCA, Beltrán; MARTÍN-DÍAZ, Emma, and DÍAZ-PARRA, Ibán (2018), Challenging austerity: radical left and social movements in the South of Europe. London: Routledge. 180 pp..

RODRIK, Dani (2012), The globalization paradox: democracy and the future of the world economy. Harrisonburg: Norton. $171 \mathrm{pp}$.

SERRANO, Júlio Pérez (2018), Radical left in Portugal and Spain (1960-2010). In: Challenging austerity: radical left and social movements in the South of Europe. Edited by ROCA, Beltrán; MARTÍN-DÍAZ, Emma, and DÍAZ-PARRA, Ibán. London: Routledge. pp. 17-47.

SILVA, Cavaco (2015a), Discurso de Cavaco Silva sobre a formação do governo, 22 October. Available at <https://expresso.sapo.pt/politica/2015-10-22-Na- 


\section{bpsr

integra-a-comunicacao-de-Cavaco-Silva-ao-pais\#gs.FK1hhpY>. Accessed on December, 21, 2018.

SILVA, Cavaco (2015b), Posse do XXI Governo: discurso integral de Cavaco Silva, 26 November. Available at <https://expresso.sapo.pt/politica/2015-11-26-Naintegra-o-discurso-de-Cavaco-Silva-na-tomada-de-posse-de-Costa\#gs.xVJFIkw>. Accessed on December, 21, 2018.

TIAGO, Lucília (2016), Acordo deixa cair salário mínimo de 600 Euros em 2019. Diário de Notícias, December 23, 2016. Available at $<$ https://www.dn.pt/dinheiro/acordo-deixa-cair-salario-minimo-de-600-eurosem-2019-5568121.html . Accessed on August, 03, 2020. 